Article

\title{
Comparative Analysis on Citizen's Subjective Responses Related to Their Willingness to Pay for Renewable Energy in Japan Using Latent Variables
}

\author{
Ryoko Nakano $^{1, *}$, Tomio Miwa ${ }^{2}$ and Takayuki Morikawa ${ }^{3, *}$ \\ 1 Institute of Global Environmental Strategies, Kanagawa Prefecture 240-0015, Japan \\ 2 Institute of Materials and Systems for Sustainability, Nagoya University, Nagoya 464-0819, Japan; \\ miwa@nagoya-u.jp \\ 3 Institute of Innovation for Future Society, Nagoya University, Nagoya 464-0819, Japan \\ * Correspondence: r-nakano@iges.or.jp (R.N.); morikawa@nagoya-u.jp (T.M.)
}

Received: 5 June 2018; Accepted: 5 July 2018; Published: 11 July 2018

\begin{abstract}
This paper focuses on understanding the difference between East and West Japan with respect to citizens' subjective views on renewable energy. A comparative analysis was performed for cities in the east and west because renewable energy is a natural resource unique to each location and suitable for a distributed energy network operated under the autonomy of the local community. This paper indicates that the social acceptance of renewable energy and willingness to pay in East Japan is affected by the citizens' strong concerns about the global environment and willingness to participate in policy-making, while the support of the deregulation of the retail electricity market and development of a distributed power system is more relevant in West Japan.
\end{abstract}

Keywords: renewable energy; social acceptance; willingness to pay; structural equation model; ordered probit model

\section{Introduction}

The context of the current debate on technology transitions is that if they are to contribute to the United Nations (UN) Sustainable Development Goals (SDGs) or the Paris climate agreement, a mixture of policy actions, public and private sector investments, and changes in consumer choices and behavior is needed. Energy system transitions have now become global phenomena. In the case of Japan, the quest for clean energy was mainstreamed after the government enacted multiple regulations and schemes following the accident at the Tokyo Electric Power Corporation (TEPCO)'s Fukushima Daiichi Nuclear Power Plant in the Fukushima prefecture in 2011. The country experienced energy savings spearheaded by the national government and supported by coordinated efforts by local governments, businesses, and citizens, which divided the country into people who oppose and those who support nuclear power. The confidence in safety citizens had felt with respect to nuclear power was deeply disturbed after being exposed to the reality of nuclear radiation. The International Commission on Radiological Protection (ICRP) determined an allowable public exposure of $1 \mathrm{mSv}$ or less per year and an aggregated lifetime exposure up to $100 \mathrm{mSv}$. Immediately after the nuclear power plant accident, the air and oceans showed high levels of contamination, in addition to that found in dairy and meat products from nearby farms and tea leaves, mushrooms, and seaweed. Some citizens chose to move to a different location out of fear for the health of their family. The local farming and fishing industry voluntarily withheld their products; they were seriously affected economically. Tokyo Electric was liable to compensate for such impacts.

Due to the contamination and the electricity shortage that followed the halt of the nuclear plant operations, which affected the nation both economically and socially, the national government of Japan 
introduced the feed-in tariff for renewable energy sources in July 2012 to promote a shift in the energy mix. As a result, the retail markets for households and small and middle-sized enterprises (SME) were liberated in April 2016. In total, 515 new power generators and 418 new retail service providers [1] were registered. Citizens will be able to choose energy services from local power generators that produce energy from local renewable energy sources. Japan has pledged to reduce the greenhouse gas emissions by $26 \%$ from 2013 to 2030 and increase the level of renewables in the energy mix for electricity to $22 \%-24 \%$ (as of 2012 , it is $~ 10 \%$ ) [2]. As of 2017, the level of renewable energy (excluding that of hydropower) is still insignificant at only $6 \%$.

Meanwhile, Germany has promoted energy transitions through a policy known as "Energiewende", which includes several pledges: reduce $\mathrm{CO}_{2}$ levels by $80 \%-90 \%$ percent compared with 2005 levels by 2050; remove nuclear power by 2022; and realize a stable energy supply by strategically increasing renewable energy within the energy mix; and reducing the energy consumption [3]. A rise in renewables would allow for the transition from large concentrated energy systems that depend on fossil fuel to a more distributed system that consists of small power generators, which are financed and operated locally with the involvement of the community [4]. In Germany, over half of the power generators using renewables are invested in by citizens or the local communities [5]. National subsidies for wind power generation (100 MW of wind), the 1000 roof programme for photovoltaic (PV)s, and feed-in tariffs are also part of this movement. The German energy system therefore consists of both centralized and decentralized energy systems; renewables account for $28 \%$ of the energy, excluding hydropower [6].

Other countries have also succeeded in transitioning. Sweden and the United Kingdom (UK) have been following a milder transition compared with Germany. They are maintaining nuclear power while inducing increased generation of renewables using policies such as the renewable quota system. Sweden's hydro- and nuclear power supply decreased from $\sim 95 \%$ in the early 2000 s to slightly below $81 \%$ in 2016 [7]. In the UK, wind power has been the strongest source of growth due to the renewable quota "Renewable Obligations (RO)," designed for large power generators, and a feed-in tariff for small-scale installations. Furthermore, nuclear power will remain a substantial source of electricity because the UK government is now committed to the construction of a new nuclear power station [8]. Another example is Denmark, where coal has been replaced by renewable sources (wind, biofuels and waste, and solar), which now account for $63 \%$ of the total electricity generation, while also relying on imports from Sweden, Norway, and Germany with respect to the supply of electricity [9].

In Japan, efforts are being made to reach the $22 \%-24 \%$ target by using feed-in tariffs and a deregulation of the retail electricity market. For further energy transitions to be made, behavioral changes have to be promoted in the future; a transition of social norms, that is, acceptance of renewables, is required.

This paper contributes to the literature in that it discusses the citizens' willingness to pay (WTP) and the regional differences between East and West Japan and in addition, because it shows possible policies that could be applied to allow for higher support from citizens. Lastly, the combination of the structure equation and probit models for latent variable modeling is another contribution of this study to existing literature.

The remainder of the paper is divided into five sections. The following section reviews literature on possible energy-saving measures. The data sources are explained in Section 3. Section 4 introduces the research framework. Section 5 discusses the outcome of the data and future research areas.

\section{Literature Review}

An energy transition most broadly involves the change of an energy system and usually starts from the point at which a system or technology occupies a $1 \%$ market share until it rises to $25 \%$ [10] or $50 \%$ [11] of the national or global market share. The transition of a system is more complex than that of a single technology because it requires fundamental changes of the technology, political and legal regulations, economies of scale and price signals, and social attitudes and behavior of users and adopters [12,13]. Once multiple technologies are included, transcending over regions and markets, 
the speed at which a transition occurs is slow. Usually, a prototype of the new system is developed in a protected area and then diffusion proceeds via a leader-follower pattern in time and space. The protected area is useful to reduce any influence from incumbent players. In the case of Germany, transitions have occurred, where the government plays a stronger role, underpinned by green political support. The benefits of grassroots innovations for sustainable development are principally due to the creation of space for developing new ideas and progressive practices on a small scale [14]. The UK has managed to increase the level of renewables in the energy mix by maintaining the level of nuclear power and carefully choosing smaller changes of sustainable practice in energy systems and delegating a high degree of responsibility to incumbent actors [15]. In the case of Japan, the technologies, political and legal regulations, economies of scale, in other words, the institutional setting in support of the renewable energy supply, and the network of actors that would install these changes seem to be ready $[16,17]$. Regardless, the transitions might not reach their full speed because Japan's energy system, similar to that of the UK, is locked-in, allowing for transitions to occur within a range that incumbent power generators permit [18].

However, why do transitions in systems occur in the first place? To be more specific, why are some countries more successful than others in the transition to renewables? This depends on whether an equitable distribution of benefits based on the transition from fossil fuel to renewables can be realized in the society. In the case of Germany, Denmark, and Sweden, the limited level of access to fossil fuel seems to have led to a movement to "secure" alternative energy resources and make electricity services "affordable" to all, while becoming champions in the global quest for "mitigating climate change" [11]. Others would argue that the social acceptance of renewables should increase only when the equity among the society is realized by removing the barriers of cost and knowledge that create a divide between proponents and opponents [19].

There is a substantial amount of literature on the social acceptance of renewables in Japan and other countries. According to Walker [20,21], local policy deliberation procedures must be transparent and participatory for citizens to gain consensus among the local society. Fujii [22] argues that installing decentralized technology would be difficult in Japan because the social systems outside of megacities are still centralized and suggests that the role of communities will be even more important. On the other hand, Shirai [23] hypothesized based on case studies of Iida City (Nagano Prefecture) and Konan City (Shiga Prefecture) that the "social equity," "environmental coexistence," and "independence and regeneration" of the local society is instrumental in reaching that target. Furthermore, Toyota [24] compared case studies of the Fukushima Prefecture, Kyoto City, and Tama region and concluded that "equity" and "assurance of safety" are reasons for citizens to consider renewables based on the following terms: (1) the endeavor is partially invested in by citizens; (2) citizens participation in the decision-making about the construction and operation of a power utility is favored; (3) revenues are returned in some way or another to the citizens and local community; and (4) the actions will contribute to some extent to counter climate change and energy issues. For other power sources, such as nuclear power, Kimura [25] suggested that citizens should first decide on their position for or against nuclear power plants based on the level of necessity and availability and then by balancing their trust towards the national government and power generators and the nuclear risk and antipathy for the technology. Existing literature does not provide much information on risks or insecurities, which might be an interesting area of research.

Social acceptance can be analyzed using quantitative measures such as WTP. There is a vast amount of accumulated studies on the WTP for renewable surcharges, which are mostly based on logit and probit models. Examples are shown in Table 1. 
Table 1. Literature on the willingness to pay (WTP) for renewables surcharges.

\begin{tabular}{|c|c|c|c|c|c|c|}
\hline Authors & Country & Survey & $\mathbf{N}$ & Methodology & Main Findings & Issues \\
\hline Lee et al. (2018) [26] & South Korea & $\begin{array}{l}\text { Interview } \\
(2017)\end{array}$ & 1000 & Mixture model & $\begin{array}{l}\text { Half of the respondents } \\
\text { stated zero WTP for solar } \\
\text { photovoltaics (PV) }\end{array}$ & \\
\hline $\begin{array}{c}\text { Ntanos et al. (2018) } \\
\text { [27] }\end{array}$ & Greece & $\begin{array}{l}\text { Election } \\
\text { poll (2016) }\end{array}$ & 400 & Logit model & $\begin{array}{l}\text { Education, subsidies, and } \\
\text { state actions are positive }\end{array}$ & $\begin{array}{l}\text { Geographic } \\
\text { distribution }\end{array}$ \\
\hline $\begin{array}{c}\text { Jungwoo, Won-Sik } \\
\text { (2017) [28] }\end{array}$ & South Korea & $\begin{array}{l}\text { Interview } \\
(2012)\end{array}$ & 498 & $\begin{array}{l}\text { Multinomial } \\
\text { probit }\end{array}$ & $\begin{array}{l}\text { WTP for renewable fuel } \\
\text { changes by income }\end{array}$ & \\
\hline Chen et al. (2017) [29] & Hong Kong & $\begin{array}{l}\text { Telephone } \\
\text { (2017) }\end{array}$ & 1460 & $\begin{array}{l}\text { Logit and probit } \\
\text { model }\end{array}$ & $\begin{array}{l}\text { Decarbonization is highly } \\
\text { supported }\end{array}$ & \\
\hline Sun et al. (2016) [30] & China & $\begin{array}{l}\text { Interviews } \\
\quad(2013)\end{array}$ & 849 & Probit model & $\begin{array}{l}\text { WTP to prevent nuclear } \\
\text { power generation }\end{array}$ & \\
\hline $\begin{array}{l}\text { Lee and Hyejin (2016) } \\
\text { [31] }\end{array}$ & South Korea & $\begin{array}{l}\text { Interview } \\
(2014)\end{array}$ & 1000 & Semi-spike model & $\begin{array}{l}\text { Korea's WTP is very low } \\
\text { in advanced countries }\end{array}$ & \\
\hline
\end{tabular}

This study aims to identify whether the causes for social acceptance of renewables can be quantitatively proven. There is literature on the demand analysis for different power sources and renewable energy technology [32]. Quantitative analysis for social decision-making procedures for renewables and research to identify causal variables for citizens to choose renewable energy technology, have also been conducted [33].

\section{Data}

\subsection{Data Collection}

A web survey was conducted from 1-29 October 2012, in five cities, that is, Kawasaki City, Yokohama City, Nagoya City, Matsuzaka City and neighboring cities/towns in the Mie Prefecture, and Kitakyushu City. The purpose of the survey questions was to see how the nuclear accident in Fukushima had changed the attitudes and beliefs about nuclear safety, whether citizens were ready for a transition to a new energy system with more renewables, and what they would be willing to do for it to happen. The web marketing company randomly selected 1000 households in each city from their registered pool of respondents and data were gathered from a total of 5000 households. The age of the respondents of different households ranged from 20 to 69 . The samples were selected to reflect the age of the population. The number of samples was kept the same (1000) to allow a comparison.

Table 2 shows the response to questions on the willingness to invest in renewable power generation, participate in the policy decision-making process, attitudes about climate change and energy issues, and support for deregulation of the electricity market. Table 3 shows that there was a tendency to save more energy after the nuclear power accident. Based on the comparison between East Japan (Yokohama and Kawasaki) and West Japan (Nagoya, Matsuzaka, and Kitakyushu), respondents in the east would save energy at home, in the community, and at work and switch off electric appliances with standby electricity functions at regular intervals. Furthermore, more respondents in East Japan favored the idea of directly participating in new technology such as demand response services with smart meters and time-of-use pricing. Respondents in East Japan were very open to services based on newly established power generators ( $>60 \%$ replied "probably yes" and "yes, I think so") compared with West Japan $(>56 \%)$ when asked of "deregulation of the retail electricity market in the residential sector."

These are behaviors that are triggered by the need to reduce energy shortages in the short term but there are concerns about long-lasting challenges such as climate change and environmental degradation. The responses show that $68.5 \%$ of the people are concerned about climate change in East Japan, slightly more than in West Japan (64\%). Meanwhile, the more than $60 \%$ of the people are for the phasing out of nuclear power generation.

Social norms are moving towards accepting decentralized power generation; $62.5 \%$ of the respondents in East Japan and $57.4 \%$ of the respondents in West Japan support this trend. Furthermore, 
the results show the peoples' growing interest in responding to the call for public comments on heat and energy deregulation, which is a large transition from the existing energy governance systems developed without citizen involvement. The number of respondents who were willing to participate exceeds $60 \%$ in East Japan and 58\% in West Japan.

Another interesting fact is that the number of respondents who had experience in investing in green energy funds for generators and those who had invested in citizen funds promoting renewables was very small in both East and West Japan at the time of the survey.

Table 2. Response to the survey questions.

\begin{tabular}{|c|c|c|c|}
\hline Questions & Response (East) & & Response (West) \\
\hline \multirow{5}{*}{ Are you interested in the climate change issue? } & No & $4.0 \%$ & $4.2 \%$ \\
\hline & Not much & $6.9 \%$ & $7.7 \%$ \\
\hline & I am undecided & $20.5 \%$ & $24.1 \%$ \\
\hline & Yes, a little & $50.8 \%$ & $48.0 \%$ \\
\hline & Yes, definitely & $17.7 \%$ & $16.0 \%$ \\
\hline \multirow{6}{*}{$\begin{array}{l}\text { What are your thoughts on generating energy using nuclear generators? (Should } \\
\text { they stop? When?) }\end{array}$} & Use beyond 2050 & $19.0 \%$ & $15.9 \%$ \\
\hline & Stop by 2050 & $9.0 \%$ & $8.9 \%$ \\
\hline & Stop by 2040 & $6.0 \%$ & $7.4 \%$ \\
\hline & Stop by 2030 & $25.0 \%$ & $25.1 \%$ \\
\hline & Stop immediately & $20.0 \%$ & $21.3 \%$ \\
\hline & I am not sure & $20.0 \%$ & $21.4 \%$ \\
\hline \multirow{5}{*}{$\begin{array}{l}\text { Did the Fukushima nuclear accident prompt you to save energy in your home, } \\
\text { office, and community? }\end{array}$} & Definitely not & $3.4 \%$ & $5.2 \%$ \\
\hline & Not much & $5.0 \%$ & $6.8 \%$ \\
\hline & I am undecided & $15.6 \%$ & $19.9 \%$ \\
\hline & Yes, a little & $39.9 \%$ & $41.9 \%$ \\
\hline & Yes, definitely & & $26.2 \%$ \\
\hline \multirow{2}{*}{$\begin{array}{l}\text { Do you think electric appliances with standby electricity functions must be } \\
\text { switched off at regular intervals? }\end{array}$} & No & $37.8 \%$ & $43.7 \%$ \\
\hline & Yes & $62.1 \%$ & $56.3 \%$ \\
\hline \multirow{2}{*}{$\begin{array}{l}\text { Would you choose to save energy by participating in demand response services } \\
\text { based on smart meters and time-of-use pricing? }\end{array}$} & Probably not & $36.6 \%$ & $39.6 \%$ \\
\hline & Probably yes & $63.4 \%$ & $60.4 \%$ \\
\hline \multirow{2}{*}{ Were you aware of the deregulation of the retail electricity market? } & Not aware & $56.0 \%$ & $60 \%$ \\
\hline & Yes aware & $43.0 \%$ & $40 \%$ \\
\hline \multirow{5}{*}{ Do you support the deregulation of the retail electricity market? } & Not necessary & $1.4 \%$ & $2.9 \%$ \\
\hline & Not really necessary & $4.0 \%$ & $6.7 \%$ \\
\hline & I am undecided & $25.0 \%$ & $33.2 \%$ \\
\hline & Yes, probably & $36.0 \%$ & $33.8 \%$ \\
\hline & Yes, definitely & $32.0 \%$ & $23.4 \%$ \\
\hline \multirow{5}{*}{ Do you think a decentralized energy system should be promoted? } & No, I do not & $1.9 \%$ & $2.5 \%$ \\
\hline & Probably not & $4.6 \%$ & $4.9 \%$ \\
\hline & It could be either & $30.8 \%$ & $35.2 \%$ \\
\hline & Probably yes & $46.6 \%$ & $43.2 \%$ \\
\hline & Yes, I think so & $15.9 \%$ & $14.2 \%$ \\
\hline \multirow{3}{*}{$\begin{array}{l}\text { How would you respond to the call for public comments on the use of heat and } \\
\text { energy services in the future? }\end{array}$} & Probably not & $37.8 \%$ & $41.2 \%$ \\
\hline & Maybe & $49.3 \%$ & $46.6 \%$ \\
\hline & Will respond & $12.9 \%$ & $12.2 \%$ \\
\hline \multirow{3}{*}{$\begin{array}{l}\text { How do you feel about participating in the debate on future heat and energy } \\
\text { services? }\end{array}$} & Probably not & $70.4 \%$ & $70.7 \%$ \\
\hline & Maybe & $23.8 \%$ & $24.1 \%$ \\
\hline & Will respond & $5.7 \%$ & $5.3 \%$ \\
\hline \multirow{3}{*}{$\begin{array}{l}\text { Would you participate in discussions about future heat and energy services if } \\
\text { requested? }\end{array}$} & Probably not & $59.5 \%$ & $59.0 \%$ \\
\hline & Maybe & $32.7 \%$ & $33.7 \%$ \\
\hline & Will respond & $7.8 \%$ & $7.3 \%$ \\
\hline \multirow{2}{*}{$\begin{array}{l}\text { Have you invested in the green electricity funds that support the power } \\
\text { generation using renewables? }\end{array}$} & No & $92.7 \%$ & $92.9 \%$ \\
\hline & Yes & $7.2 \%$ & $7.1 \%$ \\
\hline \multirow{2}{*}{$\begin{array}{l}\text { Have you invested in citizen funds that would promote renewable power } \\
\text { generation by citizens? }\end{array}$} & No & $98.0 \%$ & $98.2 \%$ \\
\hline & Yes & $2.0 \%$ & $1.8 \%$ \\
\hline
\end{tabular}


Table 3. Sample attributes.

\begin{tabular}{|c|c|c|c|c|}
\hline & & & Samples & Ratio \\
\hline \multirow[b]{2}{*}{ Gender } & & Male & 2864 & $57.3 \%$ \\
\hline & & Female & 2136 & $42.7 \%$ \\
\hline Age & & Average & 44 & \\
\hline \multirow{5}{*}{ Location } & \multirow{3}{*}{ East } & Yokohama City (population) & $1000(3,703,998)$ & $20.0 \%$ \\
\hline & & Kawasaki City (population) & $1000(1,448,196)$ & $20.0 \%$ \\
\hline & & Nagoya City (population) & $1000(2,263,894)$ & $20.0 \%$ \\
\hline & \multirow{2}{*}{ West } & Matsuzaka City, etc. (population) & $1000(688,916)$ & $20.0 \%$ \\
\hline & & Kita Kyushu City (population) & $1000(974,287)$ & $20.0 \%$ \\
\hline \multirow{2}{*}{ Final education } & & High school & 2474 & $49.5 \%$ \\
\hline & & Undergraduate and above & 2526 & $50.5 \%$ \\
\hline \multirow{5}{*}{ Annual income } & & $0-3$ million & 777 & $15.5 \%$ \\
\hline & & 3-5 million & 1264 & $25.3 \%$ \\
\hline & & 5-7 million & 1222 & $24.4 \%$ \\
\hline & & 7-10 million & 1044 & $20.9 \%$ \\
\hline & & 10 million and above & 693 & $13.9 \%$ \\
\hline \multirow{2}{*}{ Employment } & & nemployed, temporarily employed & 1403 & $28.1 \%$ \\
\hline & & Regular employment & 3597 & $71.9 \%$ \\
\hline \multirow{2}{*}{ Ownership of homes } & & Rented homes & 1605 & $32.1 \%$ \\
\hline & & Owned homes & 3395 & $67.9 \%$ \\
\hline
\end{tabular}

Note: The figures in parentheses represent the population of each municipality based on the demographic statistics from 2012-2013. Matsuzaka City, etc., refers to the following cities in the Mie Prefecture: Matsuzaka City, Ise City, Toba City, Shima City, Tamaki City, Meiwa Town, Taki Town, Odai Town, Watarai Town, Taiki Town, Iga City, Nabari City, Otaka City, Kihoku Town, Kumano City, Ohama Town, and Kiho Town.

\subsection{Willingness to Pay for Renewables}

The survey contained questions on the respondent's individual attributes and their WTP for electricity surcharges for renewable power generation using card payments. The Japanese government has developed a system in which all power generated by renewables is purchased at a fixed price for a predetermined number of years (feed-in tariff) to scale the distribution of solar and wind power and other renewables. The costs for the purchase will be collected from electricity consumers at a fixed price as a surcharge for the local electricity generators together with their conventional electricity bills. The collected surcharge will be sent to an adjustment agency that checks imbalances between the surcharge collected from the consumers and tariffs that should be paid to the utility registered for the feed in tariff (FIT). Subsequently, the imbalance amount is remitted. In October 2012, the FIT occurred only three months after its implementation. In this paper, the Contingent Valuation Method (CVM) is used, which is frequently applied to estimate the value that a person perceives with respect to a good. The approach asks people to directly report their WTP to obtain a specified good or willingness to accept (WTA) to give up a good, rather than making inferences based on observed behavior in the regular market. The following question was asked to estimate the WTP for electricity surcharges. The monthly payment for electricity between July and September 2012 for an average household (2.7 members) with an income of 435,791 JPY was 7689 JPY [34].

"With less nuclear power, the alternative scenario would be to have more fossil fuel (coal, natural gas, and oil), which would lead to further $\mathrm{CO}_{2}$ emissions. We could exit this path by substantially increasing the ratio of power generated from renewables. This would, however, require some financial contributions from the community. If so, what is the maximum amount you are willing to contribute per month? Please choose from the following options: (1) I have no intention to pay anything in addition to the current monthly electricity charges; (2) 1000 yen per month; (3) 2000 yen per month; (4) 3000 yen per month; and (5) 4000 yen per month".

In this article, the payment card approach was used when determining the WTP, which is more efficient compared with other approaches. The payment card approach has been criticized because an inappropriate choice of bid range and distribution of the choice displayed may introduce information 
and truncation biases. The bias, in other words, points to the possibility that respondents could choose the mean option and try to steer away from minimum or maximum options. The option "I have no intention to pay anything in addition to the current monthly electricity charges" chosen by the respondent could mean that their WTP is below zero yen and they are hoping to receive compensation for any negative environmental damage incurred, as in the case of wind power generation.

Figure 1 shows the distribution of the WTP. The mean value for both East and West Japan is approximately 2000 yen per month. The difference of the shape of the distribution between the two regions is small.

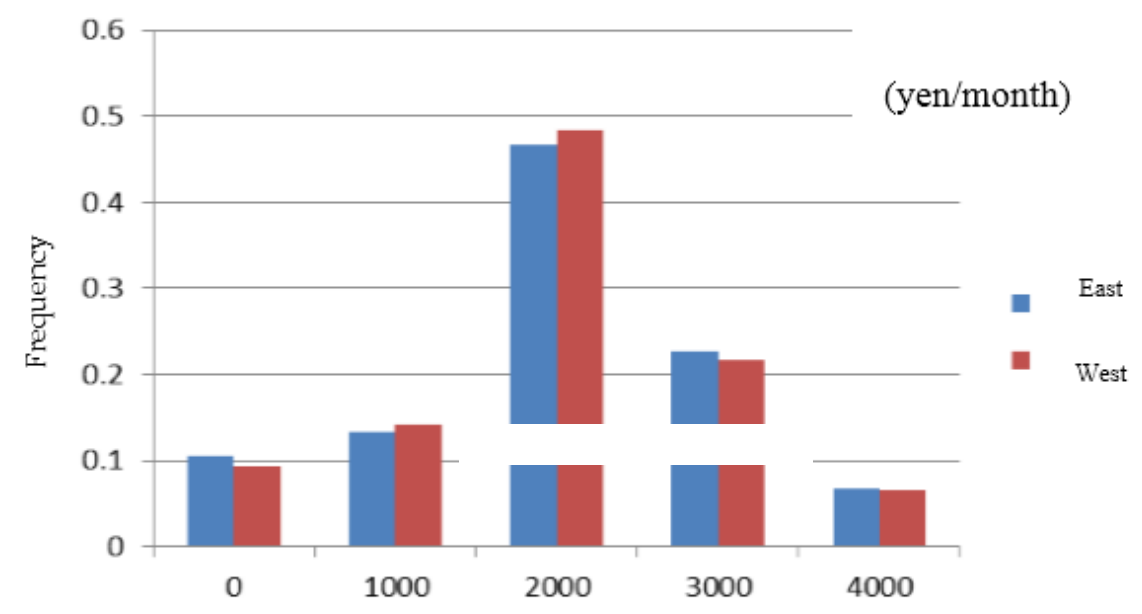

Figure 1. Distribution of the willingness to pay.

\section{Research Framework}

This article analyzes the reasons for the subjective views of citizens, that is, social acceptance of power generation using local renewable resources through key concepts found in the literature review such as interest in investment, participatory intentions, conscious level of the challenges with respect to climate change and energy, and support for deregulation of the electricity market (Step 1 in Figure 2). Next, the study sought to identify the reasons of social acceptance for renewables by determining the level of correlation between the latent variables and other subjective variables, which were used to define the WTP for electricity surcharges in the previous section (Step 2 in Figure 2). The dataset was separated into two parts: West Japan and East Japan. Modeling was separately conducted for each region based on the same variables to compare the citizen's preferences between west and east.

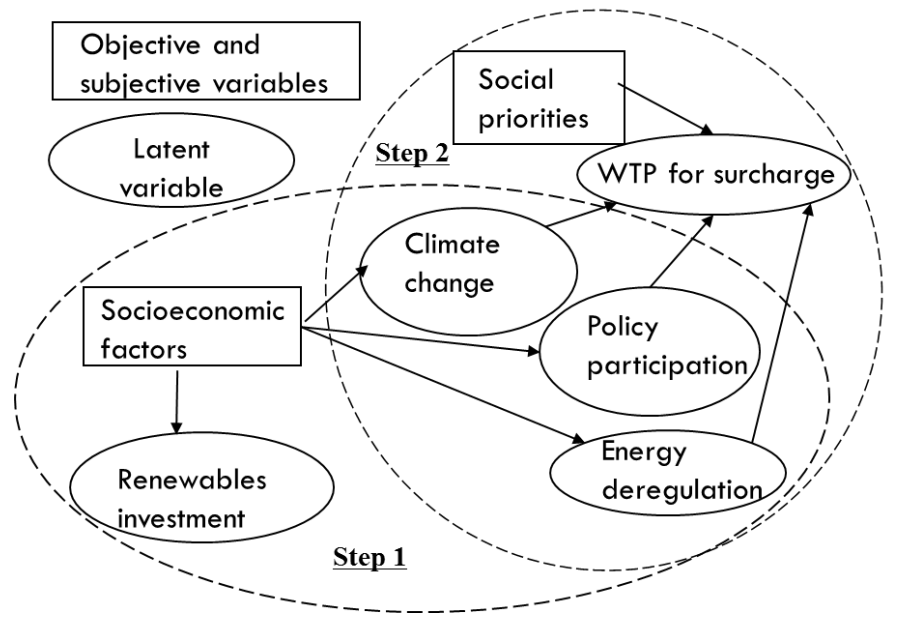

Figure 2. Evaluation model. 


\subsection{Structural Equation Modeling}

This chapter uses structural equation modeling (SEM) to analyze the reasons for supporting electricity deregulation. The SEM combines techniques that are common with factor analysis and multivariate regression, to group the observed variables with similar characteristics into constructs/latent variables, and then determine the relationship between the different constructs/latent variables. It consists of two models (Figure 3), that is, the measurement model that connects the latent (unobserved) variables with the observed variables (i.e., an individual's views and responses to a question) and the structural model that relates the latent variables and the individual's social and economic characteristics. We used LISREL 9.2 to estimate the model. The following equations were used.

$$
\begin{gathered}
\text { [Measurement model }] \mathrm{y}_{i}=\mathrm{K}_{i}+\Lambda \mathrm{x}_{i}+\varepsilon_{i} \\
{[\text { Structural model }] \eta_{i}=\mathrm{B} \eta_{i}+\Gamma \mathrm{x}_{i}+\zeta_{i}}
\end{gathered}
$$

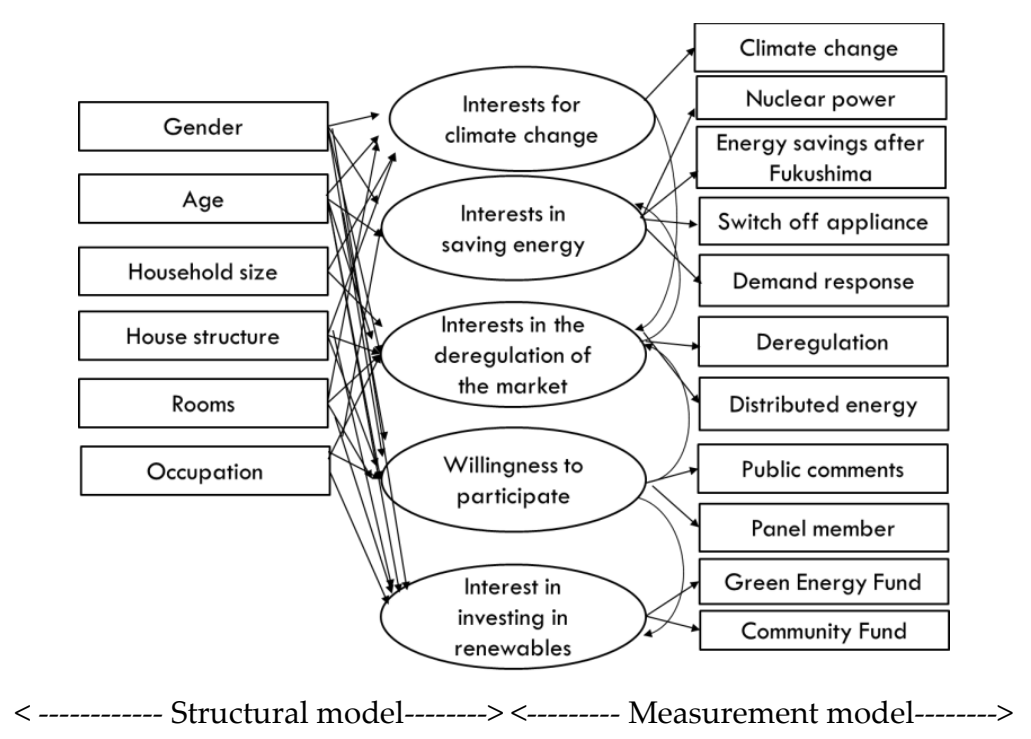

Figure 3. Structural equation model.

For each individual $i, \eta_{i}$ is the latent variable; vectors $\mathrm{y}_{i}$ and $\mathrm{x}_{i}$ are observed dependent variables and independent variables, respectively; $\mathrm{B}, \Gamma, \mathrm{K}$, and $\Lambda$ stand for unknown parameters; and $\zeta_{i}$ and $\varepsilon_{i}$ represent the residuals. Several measures were used for the overall assessment of the model fit: goodness of fit index (GFI), adjusted goodness of fit index (AGFI), and root-mean-square residual (RMSR).

The latent variables are factors that determine the citizen's choice and behavior in the measurement model, that is, the respondents' "interests in climate change," "interest in saving energy on a daily basis," "interest in the deregulation of the electricity market," "willingness to participate in a policy planning process/consciousness level with respect to energy savings," and "interest in investing in renewable power generation." The coefficients between the observed dependent variables and the latent variables for the measurement model are listed in Table 4 . Table 4 shows that all coefficients statistically differ from zero.

The correlation coefficients between the latent variable and the independent variables for the structural model are defined in Table 5. The independent variables are socioeconomic characteristics including gender, age, and house structure. The results in Table 4 indicate that the gender and household size effects energy-related decisions. In East Japan, respondents who were more conscious about global environment issues showed strong energy-saving tendencies. Men, however, are more inclined to participate in policy-making procedures because they have experience in similar activities 
at the workplace. Respondents with larger families have the tendency to show a higher interest in climate change and saving more energy. Their income levels, however, tend to be relatively low, reducing their interest in saving energy. The interest in the deregulation of the electricity market is higher for senior respondents with higher levels of education, possibly because it is not a topic that is typically discussed among family members with young children. The interest in investing in renewables is higher for respondents who live in detached houses compared with those who live in apartments and compounds. The results in West Japan are similar, except for gender. Women in West Japan are more prone to actively engage in policy planning procedures. The support of deregulation and energy saving is high. Women seem to lead the communities regarding energy and environment issues. Another interesting result is that younger citizens support the deregulation in West Japan (not seniors, as in East Japan).

Table 4. Observed variables and correlation coefficients (measurement models).

\begin{tabular}{|c|c|c|c|}
\hline Latent Variables & Observed Subjective Variables & East Japan & West Japan \\
\hline \multirow{2}{*}{ Interest in climate change } & Are you interested in climate change issues? & 1.00 & 1.00 \\
\hline & $\begin{array}{l}\text { What are your thoughts on generating energy from nuclear } \\
\text { generators? (Should they stop? When?) }\end{array}$ & $0.99 *$ & $0.31 *$ \\
\hline \multirow{3}{*}{$\begin{array}{l}\text { Interest in saving energy on a } \\
\text { daily basis }\end{array}$} & $\begin{array}{l}\text { Did the Fukushima nuclear accident prompt you to save } \\
\text { energy in your home, office, and community? }\end{array}$ & 1.00 & 1.00 \\
\hline & $\begin{array}{l}\text { Do you switch off electric appliances with standby electricity } \\
\text { functions at regular intervals? }\end{array}$ & $0.24 *$ & $0.54 *$ \\
\hline & $\begin{array}{l}\text { Would you participate in demand response services with } \\
\text { time-of-use pricing that save energy by installing smart } \\
\text { meters? }\end{array}$ & $0.34 *$ & $0.71 *$ \\
\hline \multirow{3}{*}{$\begin{array}{l}\text { Interest in the deregulation of the } \\
\text { electricity market }\end{array}$} & $\begin{array}{l}\text { Are you aware of the deregulation of the retail electricity } \\
\text { market? }\end{array}$ & 1.00 & 1.00 \\
\hline & $\begin{array}{l}\text { Do you welcome the deregulation of the retail electricity } \\
\text { market? }\end{array}$ & $0.62 *$ & $1.69^{*}$ \\
\hline & $\begin{array}{l}\text { Do you welcome the deregulation of the retail electricity } \\
\text { market? }\end{array}$ & $1.28 *$ & $1.77^{*}$ \\
\hline \multirow{3}{*}{$\begin{array}{l}\text { Willingness to participate in a } \\
\text { policy planning process }\end{array}$} & $\begin{array}{l}\text { Would you respond to calls for public comments on new heat } \\
\text { and energy use measures? }\end{array}$ & 1.00 & 1.00 \\
\hline & $\begin{array}{l}\text { Would you nominate yourself as a member on a panel that } \\
\text { discusses future heat and energy policies? }\end{array}$ & $1.25 *$ & $1.19^{*}$ \\
\hline & $\begin{array}{l}\text { Would you accept an offer to serve as a panel member for } \\
\text { discussions on future heat and energy policies? }\end{array}$ & $1.22 *$ & $1.24 *$ \\
\hline \multirow{2}{*}{$\begin{array}{l}\text { Interest in investing in renewable } \\
\text { energy }\end{array}$} & $\begin{array}{l}\text { Have you invested in green energy funds for power } \\
\text { generators facilitating renewable power? }\end{array}$ & 1.00 & 1.00 \\
\hline & $\begin{array}{l}\text { Have you ever invested in community funds that promote } \\
\text { renewable projects by the community? }\end{array}$ & $0.72 *$ & $0.46^{*}$ \\
\hline
\end{tabular}

Note: The asterisk * indicates that the coefficients statistically differ from zero at the $5 \%$ significance level.

Figure 4 shows the relationship between the latent variables. Figure $4 \mathrm{a}$ shows that the coefficient relating the latent variables "climate change" with "participation in the policy planning process" for East Japan is significant. Respondents who are more interested in climate change and energy issues tend to support participation in this area. The coefficient relating the latent variables "participation in policy planning procedures" with "deregulation of the electricity market" is also significant, showing that participants would possibly serve to promote the deregulation and decentralizing of the energy system.

Furthermore, the coefficient relating the latent variables "deregulation of the electricity market" with "daily energy-saving behavior" is significant, indicating those who support the deregulation have a higher probability of behaving in a specific way, that is, saving energy. Lastly, the coefficient relating "participation in the policy decision-making" with "interest in investing in renewables" is significant, showing that the investment in renewables might provide an opportunity to participate in policy design. While there are similarities to East Japan, the results differ in West Japan. The "interest in climate change" is high and the "interest in participation in policy planning procedures" is low. The reasons for this outcome need to be determined in future research. 
Table 5. Independent variables and latent variables (structural model).

\begin{tabular}{|c|c|c|c|}
\hline Latent Variable & Independent Variable & East & West \\
\hline \multirow{7}{*}{ Interest in climate change } & Gender & $0.24 *$ & $0.07 *$ \\
\hline & Age & $0.02 *$ & 0.17 * \\
\hline & Income & 0.03 & 0.01 \\
\hline & Final education & $0.09 *$ & $0.07 *$ \\
\hline & Household size & $0.04 *$ & $0.04 *$ \\
\hline & House age & -0.03 & $-0.07^{*}$ \\
\hline & House owner & 0.03 & $0.02 *$ \\
\hline \multirow{6}{*}{ Interest in saving energy on a daily basis } & Interest in deregulation (latent variable) & $0.88 *$ & $1.42 *$ \\
\hline & Gender & $0.23 *$ & $0.16^{*}$ \\
\hline & Age & 0.0003 & -0.02 \\
\hline & Household size & 0.06 * & 0.04 \\
\hline & House age & -0.04 * & -0.04 \\
\hline & House structure & 0.007 & $0.05 *$ \\
\hline \multirow{8}{*}{$\begin{array}{l}\text { Interest in the deregulation of the } \\
\text { electricity market }\end{array}$} & $\begin{array}{l}\text { Willingness to participate in policy-making (latent } \\
\text { variable) }\end{array}$ & $0.38 *$ & $0.26 *$ \\
\hline & Gender & -0.02 & $-0.02 *$ \\
\hline & Age & 0.004 * & $-0.03 *$ \\
\hline & Income & 0.01 & 0.02 \\
\hline & Final education & $0.04 *$ & $0.02 *$ \\
\hline & House age & -0.0006 & $-0.02 *$ \\
\hline & House owner & -0.01 & $0.02 *$ \\
\hline & House structure & 0.02 & -0.005 \\
\hline \multirow{6}{*}{$\begin{array}{l}\text { Willingness to participate in a policy } \\
\text { planning process }\end{array}$} & Interests for climate change (latent variable) & $0.73 *$ & $-3.89 *$ \\
\hline & Gender & $-0.35^{*}$ & $0.19 *$ \\
\hline & Age & -0.0009 & $0.70 *$ \\
\hline & Income & -0.005 & $0.08 *$ \\
\hline & Final education & 0.008 & $0.31 *$ \\
\hline & Household size & -0.01 & $0.18^{*}$ \\
\hline \multirow{6}{*}{ Interest in investing in renewable energy } & Willingness to participate in policy (latent variable) & $0.29 *$ & $0.21 *$ \\
\hline & Income & $0.04 *$ & -0.01 \\
\hline & Final education & -0.02 & 0.014 \\
\hline & Household size & $-0.04 *$ & -0.000 \\
\hline & House structure & $-0.08^{*}$ & -0.03 \\
\hline & Elevator & -0.05 & -0.05 \\
\hline
\end{tabular}

Note: The asterisk * indicates that the coefficients statistically differ from zero at the $5 \%$ significance level. Gender (0: male, 1: female), Occupation (0: temporary, 1: permanent), Education (0: junior high, 1: high, 2: junior university, 3: undergrad and above), House structure ( 0 : wooden, detached; 1 : concrete, detached; 2 : reinforced concrete apartment; 3: steel-framed apartment), Elevator (0: no, 1: yes).

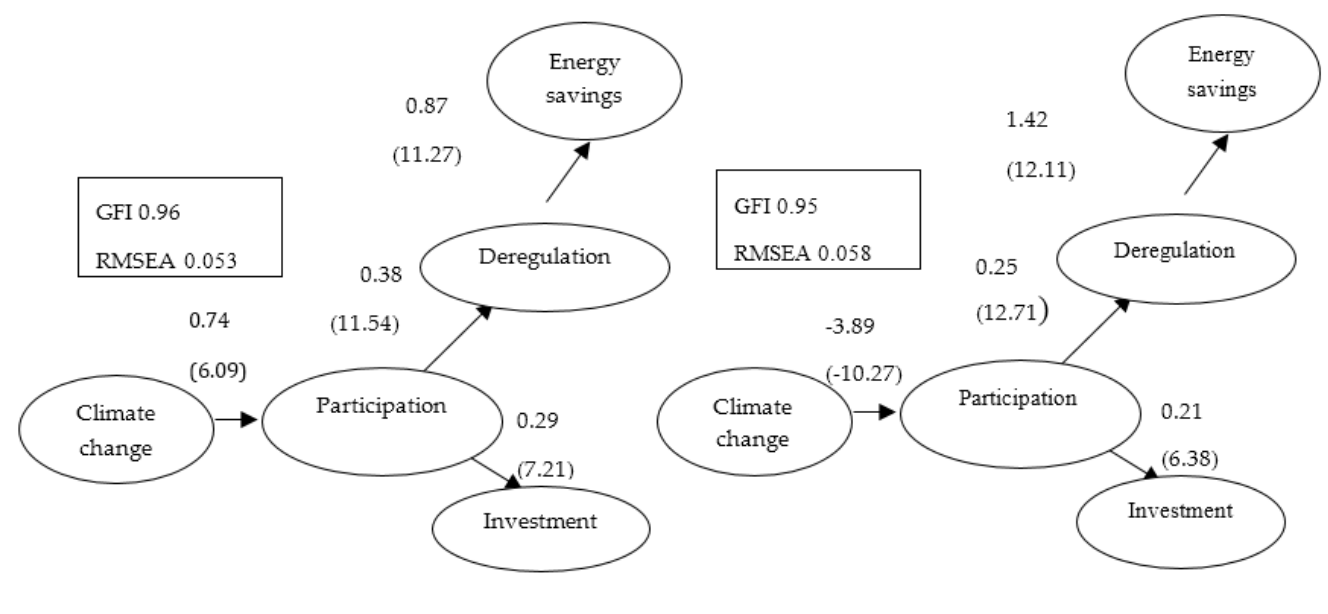

(a)

(b)

Figure 4. Relationship between the latent variables: (a) East Japan; (b) West Japan.

In this article, it was assumed that social acceptance of renewables reflects the WTP for electricity surcharges and a discrete choice model was developed followed by the analysis of reasons of citizens to choose to accept renewables. 
The choice to "invest in renewables" points to the willingness to finance the construction of specific renewable utilities. This is different from the WTP under the current FIT system, which allows local generators to gather electricity surcharges from their customers using a uniform pricing system on behalf of an adjustment agency, which will reimburse power generators registered under FIT, as explained earlier. Citizens will invest in power generators throughout the country, not in specific utilities.

\subsection{Discrete Choice Model for the Willingness to Pay}

This article assumes that the generators that influence the WTP for electricity surcharges follow a Gaussian distribution pattern and the behavior can be calculated using an ordered probit model, which is a type of discrete choice modeling.

The following equation shows the probability of an individual $i$ to agree to paying the $k$ th price option; their utility $U_{i}$ for electricity surcharges can be calculated using the independent variable $\mathbf{X}_{i}$ and an unknown parameter vector $\beta_{i}$ :

$$
\operatorname{Prob}(k)=\Phi\left(\frac{\mu_{k+1}-\boldsymbol{\beta}_{i} \mathbf{X}_{i}}{\sigma}\right)-\Phi\left(\frac{\mu_{k}-\boldsymbol{\beta}_{i} \mathbf{X}_{i}}{\sigma}\right)
$$

where $\Phi(\cdot)$ stands for the Gaussian distribution pattern and $\sigma$ is the standard deviation for errors, which can be fixed to 1 without missing the general characteristics. The independent variables used here are all "predicted" preferences. They are based on the four latent variables calculated in Section 4.1 and dummy variables for four specific policies (environment, child rearing, education, and transport) that are conducted by the municipality. The aim of the addition of these dummy variables is to identify which government policies a respondent would mostly likely favor when spending revenues from renewable power generation. A $t$ value over 1.96 shows that the variables are statistically significant. Those below 1.0 were deleted from the table because they were not important for the analysis. The results are shown in Table 6.

Table 6. Results based on an ordered probit model.

\begin{tabular}{|c|c|c|c|c|}
\hline \multirow{3}{*}{ Independent Variables } & \multicolumn{4}{|c|}{ Coefficients } \\
\hline & \multicolumn{2}{|c|}{ East Japan } & \multicolumn{2}{|c|}{ West Japan } \\
\hline & Estimate & t Value & Estimate & t Value \\
\hline Yokohama City dummy & -0.0298 & -0.6 & & \\
\hline Kitakyushu City dummy & - & - & 0.0175 & 0.4 \\
\hline \multicolumn{5}{|c|}{ Latent variables } \\
\hline Interests to save energy on a daily basis & - & - & 0.282 & 1.7 \\
\hline Support for deregulation of the electricity market & - & - & 1.24 & $4.2 *$ \\
\hline Participation in policy planning & 1.08 & $6.0 *$ & - & - \\
\hline Interest in investing in renewables & - & - & -0.621 & -1.7 \\
\hline Interest in climate change & 0.662 & $4.4^{*}$ & - & - \\
\hline \multicolumn{5}{|c|}{ Priority policies required by the city government (subjective views) } \\
\hline "Child rearing" dummy & - & - & 0.0882 & 1.3 \\
\hline "Education" dummy & 0.196 & $2.2 *$ & 0.191 & $2.1 *$ \\
\hline "Transport" dummy & -0.293 & $-3.2 *$ & - & - \\
\hline "Environment" dummy & 0.138 & 1.8 & 0.0794 & 1.0 \\
\hline Threshold $1\left(\mu_{1}\right)$ & -1.27 & -25.6 & -1.30 & -32.5 \\
\hline Threshold $2\left(\mu_{2}\right)$ & -0.725 & -16.4 & -0.698 & -20.7 \\
\hline Threshold $3\left(\mu_{3}\right)$ & 0.548 & 12.7 & 0.610 & 18.3 \\
\hline Threshold $4\left(\mu_{4}\right)$ & 1.53 & 27.9 & 1.55 & 35.3 \\
\hline Number of samples & \multicolumn{2}{|c|}{$\mathrm{N}=1794$} & \multicolumn{2}{|c|}{$\mathrm{N}=2517$} \\
\hline Initial maximum likelihood & \multicolumn{2}{|c|}{-2887.3} & \multicolumn{2}{|c|}{-4047.7} \\
\hline Final maximum likelihood & \multicolumn{2}{|c|}{-2446.0} & \multicolumn{2}{|c|}{-3405.0} \\
\hline Coefficient of determination & \multicolumn{2}{|c|}{0.149} & \multicolumn{2}{|c|}{0.156} \\
\hline Hit ratio & \multicolumn{2}{|c|}{$46.7 \%$} & \multicolumn{2}{|c|}{$48.3 \%$} \\
\hline
\end{tabular}

The asterisk * indicates that the coefficients statistically differ from zero at the $5 \%$ significance level. 
The results for East Japan show that the WTP is significantly affected by the interest in participating in policy development and interest in climate change. These latent variables, when significantly positive, would impact the WTP for electricity surcharges and promote stronger social acceptance of renewable sources. Furthermore, respondents who have a stronger acceptance of renewables might emphasize that education policies are important for them. Most interestingly, those who prioritize transport policies have a lower level of WTP.

Respondents in West Japan who support distributed power generation and deregulation of the electricity market have a higher WTP. While not statistically significant, the interest in investing in renewables leads to a lower WTP for surcharges. This might be due to respondents who would like to maintain balanced investments, in other words, those interested in investing in a specific renewable project might want to reduce their surcharges. This is a realistic approach. Respondents in West Japan who prioritize education policies also show an acceptance of renewables. Finally, education is a key priority in both East and West Japan.

\section{Discussion}

The aim of this article was to determine whether decentralized power generation systems can be scaled in Japan, that is, financed by citizens and communities, based on the subjective attitudes of people in East and West Japan. The data show that the majority of respondents in both East and West Japan actively save energy and support the transition to a new energy system. The tendency is stronger in West Japan, which was unaffected by the nuclear power accident. The results of a statistical equation model show that citizens with a stronger interest in participating in the construction and operation of renewable energy facilities show more support for the introduction of renewables, which could lead to future citizen or community investments, similar to Germany. The support for participation in policy development is higher for men in East Japan and women in West Japan, showing that the key actors in policy development differ between regions. Respondents with higher education and seniority promote the deregulation of electricity in East Japan, while younger respondents fill that role in West Japan.

Lastly, the WTP for electricity surcharges was analyzed using an ordered probit model. The results of the structural equation model and correlation between the respondents' interest in the environment, energy, and utilities for renewables were included in the analysis. In East Japan, respondents who are interested in actively participating in energy policies show a higher WTP. The respondents were more receptive in West Japan, that is, respondents who support the decentralization of electricity generation and deregulation of the electricity market but are not exactly willing to participate have a higher WTP. Interestingly respondents who prioritize education show a higher WTP.

In this study, an average surcharge of 2000 yen per month was determined (as of October 2012). Nomura [35] reported 2166 yen per month per household in 2000, ten years prior to this survey. Hironaka's [36] calculations several years after this survey (in 2015) resulted in 686 yen per month. Therefore, it seems that the WTP has decreased since the feed-in tariff was introduced.

Future studies should clarify how citizens would like to utilize monetary or non-monetary revenues from their investments to understand what triggers communities to contribute financially. Existing research on non-monetary benefits indicated triggers such as disaster risk reduction, independence of the community [37], and strengthening of the unity within the community. Detailed research and analysis identifying the variables that contribute to the revitalization of the community should be conducted.

Author Contributions: Conceptualization, R.N. and T.M. (Tomio Miwa); Methodology, R.N. and T.M. (Tomio Miwa); Software, Lisrel 9.2.; Writing-Review \& Editing, T.M. (Tomio Miwa); Supervision, T.M. (Takayuki Morikawa).

Funding: This research was conducted with generous funding from: The Environment Research and Technology Development Fund (ERTDF) from the Ministry of Environment Japan (grant number E1105; 2011-2014); and Kanagawa Prefecture Grant (2012-2014).

Conflicts of Interest: The authors declare no conflicts of interest. 


\section{References}

1. Ministry of Economy Trade and Industry Agency of Natural Resources and Energy. Deregulation of Electricity Wholesale Market. What Has Changed? Available online: http:/ /www.enecho.meti.go.jp/about/ special/tokushu/denryokugaskaikaku/denryokujiyuka.html (accessed on 15 October 2017).

2. Global Warming Prevention Headquarters. The Nationally Determined Contributions from Japan. Available online: https://www.kantei.go.jp/jp/singi/ondanka/kaisai/dai30/yakusoku_souan.pdf (accessed on 15 October 2017).

3. Jacobsson, S.; Lauber, V. The politics and policy of energy system transformation-Explaining the German diffusion of renewable energy technology. Energy Policy 2006, 34, 256-276. [CrossRef]

4. Yilditz, O. Financing renewable energy infrastructures via financial citizen participation-The case of Germany. Renew. Energy 2014, 68, 677-685. [CrossRef]

5. Schmid, E.; Knopf, B.; Pechan, A. Putting an energy system transformation into practice: The case of the German Energiewende. Energy Res. Soc. Sci. 2015, 11, 263-275. [CrossRef]

6. International Energy Agency (IEA). Germany-Energy System Overview. Available online: https://www.iea. org/media/countries/Germany.pdf (accessed on 23 June 2018).

7. International Energy Agency (IEA). Sweden-Energy System Overview. Available online: https://www.iea. org/media/countries/Sweden.pdf (accessed on 23 June 2018).

8. International Energy Agency (IEA). UK-Energy System Overview. Available online: https://www.iea.org/ media/countries/UnitedKingdom.pdf (accessed on 23 June 2018).

9. International Energy Agency (IEA). Energy System Overview. Available online: https://www.iea.org/ media/countries/Denmark.pdf (accessed on 23 June 2018).

10. Smil, V. Energy Myths and Realities: Bringing Science to the Energy Policy Debate; Rowman and Littlefield: Washington, DC, USA, 2010; pp. 136-141. ISBN 13 978-0-8447-4328-8.

11. Gubler, A.; Wilson, C.; Nemet, G. Apples, oranges, and consistent comparisons of the temporal dynamics of energy transitions. Energy Res. Soc. Sci. 2016, 22, 18-25. [CrossRef]

12. Sovacool, B. How long will it take? Conceptualizing the temporal dynamics of energy transitions. Energy Res. Soc. Sci. 2016, 13, 202-215. [CrossRef]

13. Muhammad-Sukki, F.; Abu-Bakar, S.; Munir, A.; Yasin, S.; Ramirez-Iniguez, R.; McMeekin, S.; Stewart, B.; Rahim, R. Progress of feed-in tariff in Malaysia: A year after. Energy Policy 2014, 38, 618-625. [CrossRef]

14. Kuzemko, C.; Lockwood, M.; Mitchell, C.; Hogget, R. Governing for sustainable energy system change: Politics, context and continuity. Energy Res. Soc. Sci. 2016, 12, 96-110.

15. Darmani, A.; Arvidsson, N.; Hidalgo, A.; Albors, J. What drives the development of renewable energy technologies? Toward a typology for the systemic drivers. Renew. Sustain. Energy Rev. 2014, 38, 834-847. [CrossRef]

16. McLellan, B.; Chapman, A.; Aoki, K. Geography, urbanization and lock-in-Considerations for sustainable transitions to decentralized energy systems. J. Clean. Prod. 2016, 128, 77-96. [CrossRef]

17. Seyfang, G.; Smith, A. Grassroots innovations for sustainable development: Towards a new research and policy agenda. Environ. Politics 2007, 16, 584-603. [CrossRef]

18. Muench, S.; Thuss, S.; Guenther, E. What hampers energy system transformations? The case of smart grids. Energy Policy 2014, 73, 80-92. [CrossRef]

19. Walker, G.; Hunter, S.; Devine-Wright, P.; Evans, B. Harnessing community energies: Explaining community based localism in renewable energy policy in the UK. Glob. Environ. Politics 2007, 7, 64-82. [CrossRef]

20. Walker, G.; Devine-Wright, P. Community renewable energy. What should it mean? Energy Policy 2008, 36, 497-500. [CrossRef]

21. Walker, G. What are the barriers and incentives for community-owned means of energy production and use? Energy Policy 2008, 36, 4401-4405. [CrossRef]

22. Fujii, K.; Yamashita, H. The Building of Checklists for the Structural Regeneration of Regional Communities through Renewable Energy_An Evaluation of lida City, Nagano Prefecture and Konan City, Shiga Prefecture, in Japan. Hitotsubashi Econ. 2014, 8, 27-61. (In Japanese)

23. Shirai, N.; Kafuku, M. Factors for revitalizing rural economies using renewable energy: The case of Iida city Nagano Prefecture and Konan City Shiga prefecture. Environ. Sci. J. 2017, 30, 20-33. (In Japanese) 
24. Toyota, Y. Trend and developments of citizens' co-owned renewable energy power plants. Hosei Univ. Res. Inst. 2016, 6, 87-100. (In Japanese)

25. Kimura, H.; Yoshida, K. What factors affect decision for or against nuclear policy. J. Soc. Technol. Res. 2003, 1, 307-316. [CrossRef]

26. Lee, M.; Kim, J.; Yu, S. Public Willingness to Pay for Increasing Photovoltaic Power Generation: The Case of Korea. Sustainability 2018, 10, 1196. [CrossRef]

27. Ntanos, S.; Kyriakopoulos, G.; Chalikias, M.; Arabatzis, G.; Skordoulis, M. Public Perceptions and Willingness to Pay for Renewable Energy: A Case Study from Greece. Sustainability 2018, 10, 687. [CrossRef]

28. Shin, J.; Hwang, W. Consumer preference and willingness to pay for a renewable fuel standard (RFS) policy: Focusing on ex-ante market analysis and segmentation. Energy Policy 2017, 106, 32-40. [CrossRef]

29. Cheng, Y.; Cao, K.; Woo, C.; Yatchew, A. Residential willingness to pay for deep decarbonization of electricity supply: Contingent valuation evidence from Hong Kong. Energy Policy 2017, 109, 218-227. [CrossRef]

30. Sun, C.; Zhu, X.; Meng, X. Post-Fukushima public acceptance on resuming the nuclear power program in China. Renew. Sustain. Energy Rev. 2016, 62, 685-694. [CrossRef]

31. Lee, C.; Heo, H. Estimating willingness to pay for renewable energy in South Korea using the contingent valuation method. Energy Policy 2016, 94, 150-156. [CrossRef]

32. Morita, M.; Managi, M. Energy Mix after the Great East Japan Earthquake with Input on Demand; Research Institute on Economy Trade and Industry: Tokyo, Japan, 2013. (In Japanese)

33. Baba, M.; Tagashira, N. How to design the social decision making process for introduction of renewable energy technologies. J. Soc. Technol. Res. 2009, 6, 77. (In Japanese)

34. Japan Statistics Office. Table 1. Average of Monthly Receipts and Disbursements. Available online: http: / / www.stat.go.jp/data/kakei/index.html (accessed on 23 June 2018).

35. Nomura, N.; Akai, H. Willingness to pay for green electricity in Japan as estimated through contingent valuation method. Appl. Energy 2004, 74, 453-463. [CrossRef]

36. Hironaka, Y.; Motofuji, Y. Estimating Regional Benefits of Renewable Energy Installation Using Willingness to Pay. J. Jpn. Inst. Energy 2017, 96, 52-57. (In Japanese) [CrossRef]

37. Shirai, N. The Structural Regeneration of Regional Communities through Renewable Energy in Areas Affected by the Great East Japan Earthquake: consideration of administrative measures and resident's awareness. Hosei Univ. Sustain. Res. Inst. 2017, 7, 45-58. (In Japanese) 